\title{
ROTIFERS, AND OTHER AQUATIC INVERTEBRATES, FROM THE LARSEMANN HILLS, ANTARCTICA
}

\author{
by Herbert J.G. Dartnall
}

(with two tables and two text-figures)

Dartnal., H. J.G., 1995 (30:vi): Rotifers, and other aquatic invertebrates, from the Larsemann Hills, Antarctica. Pap. Proc. R. Soc. Tasm. 129: 17-23. https://doi.org/10.26749/rstpp.129.17 ISSN 0080-4703. Copper Beeches, 76 Lewes Road, Ditchling, Sussex BN6 8TY, UK; formerly Australian Antarctic Division, Kingston, Tasmania.

Seventeen species of rotifer ( 11 Monogononta and six Bdelloidea), three tardigrades, two arthropods, as well asprotozoans, a plathyhel minth and nematodes were found in 13 freshwater lakes in the Larsemann Hills.

Key Words: rotifers, lakes, zoogeography, Larsemann Hills, Antarctica.

\section{INTRODUCTION}

The Larsemann Hills $\left(69^{\circ} 24^{\prime}\right.$ S, $\left.76^{\circ} 20^{\prime} \mathrm{E}\right)$, situated on the Ingrid Christensen Coast of Princess Elizabeth Land, Antarctica, consist of a series of low-lying, rocky peninsulas and islands on the southern shore of Prydz Bay. This area (fig. 1), which extends over $200 \mathrm{~km}^{2}$, is ice-free during the summer and bestrewn with more than 150 freshwater lakes. In the 1990/91 and 1991/92 austral summers, the opportunity arose to determine the rotifers of some of these lakes; the results obtained are presented here.

\section{MATERIALS AND METHODS}

\section{Collection and Examination of Samples}

Samples were collected in a number of ways. On the first visit, in November 1990, the lakes were all ice-covered so a $200 \mathrm{~mm}$ diameter hole was cut with a petrol-driven ice drill. Benthic samples were then obtained by means of a handoperated baling pump, which was used to suck up the sediments and overlying water through rigid plastic tubing (after Dartnall \& Hollowday 1985). Thereafter, this apparatus was deployed from the ice edge, or hung over the side of an inflatable rubber boat when sampling Lake Scandrett. Elsewhere, a fine $(53 \mu \mathrm{m}$ mesh) plankton net was allowed to sink, so that, when retrieved, it collected samples from or just above the bottom. Finally, fragments of cyano-bacterial mats were collected from around the shoreline. These mats, which had originated from deep water, were levitated to the surface by the production of gases and subsequently were blown to the lake edge.

The samples were examined at Law Base, using a binocular dissecting microscope and a high-powered compound microscope. Drawings were made from free-swimming specimens, from living specimens kept under slight compression by means of a coverslip mounted on vaseline, and from specimens relaxed and narcotised with tetra-sodium pyrophosphate (Robotti \& Lovisolo 1972). Slides of trophi were made using polyvinyl-lactophenol (PVL), after the method of Russell (1961). A drop of PVL was put on the specimen and gentle pressure was applied to the coverslip to extrude the trophi. This method is less destructive than the usual chemical methods of extraction and preserves fine details that might otherwise be lost. It is also possible, with practice and while the PVL is hardening, to change the orientation of trophi by gently manoeuvering the coverslip.

Conductivity and $\mathrm{pH}$ measurements were made with a Hanna water-test meter.

\section{The Sampling Sites}

Whilst this work was in progress, a new map of the Larsemann Hills was issued. On this map, some of the lakes were given official names which are different from those in common usage. Lake Scandrett, for example, was previously known as Lake Nella, Lake Sibthorpe was Lake Mir, and Lake Reid was Big Lake. To avoid confusion over the naming and to identify the unnamed lakes, the "LH" numbering system devised by Gillieson et al. (1990) has been used in this paper.

Thirteen lakes on the Stornes and Mirror Peninsulas were sampled (fig. 1). They were picked, within the constraints of accessibility, logistics and time, to cover the range in lake size, depth, $\mathrm{pH}$, conductivity, water chemistry and trophic status, as determined by Gillieson et al. (1990); as such, they are thought to be representative of the whole of the Larsemann Hills, even though it was not possible to sample any of the lakes on the offshore islands. None of the lakes is particularly large - Lake Scandrett (LH72) has the largest surface area (13 ha), and Progress Lake (LH57) is easily the deepest at $34 \mathrm{~m}$ (Gillieson et al. 1990). During the winter, all of the lakes freeze to a depth of $1.5 \mathrm{~m}$. This concentrates the ions, resulting in an increase in the conductivity. This effect is, of course, most marked in shallow lakes, the waters of which become deoxygenated. When the ice melts in the spring, the conductivity falls, and the wind ensures complete mixing and restoration of the oxygen concentration.

The lakes selected for sampling included a very shallow pool - the soak (which was not included in the Gillieson et al. (1990) survey), large and deep freshwater lakes, such as Lake Progress, through smaller freshwater lakes, slightly brackish ones (salinities to $2 \%$ - LH71) and coastal pools that may be subjected to inundation by sea water ( $\mathrm{LH} 23)$. 


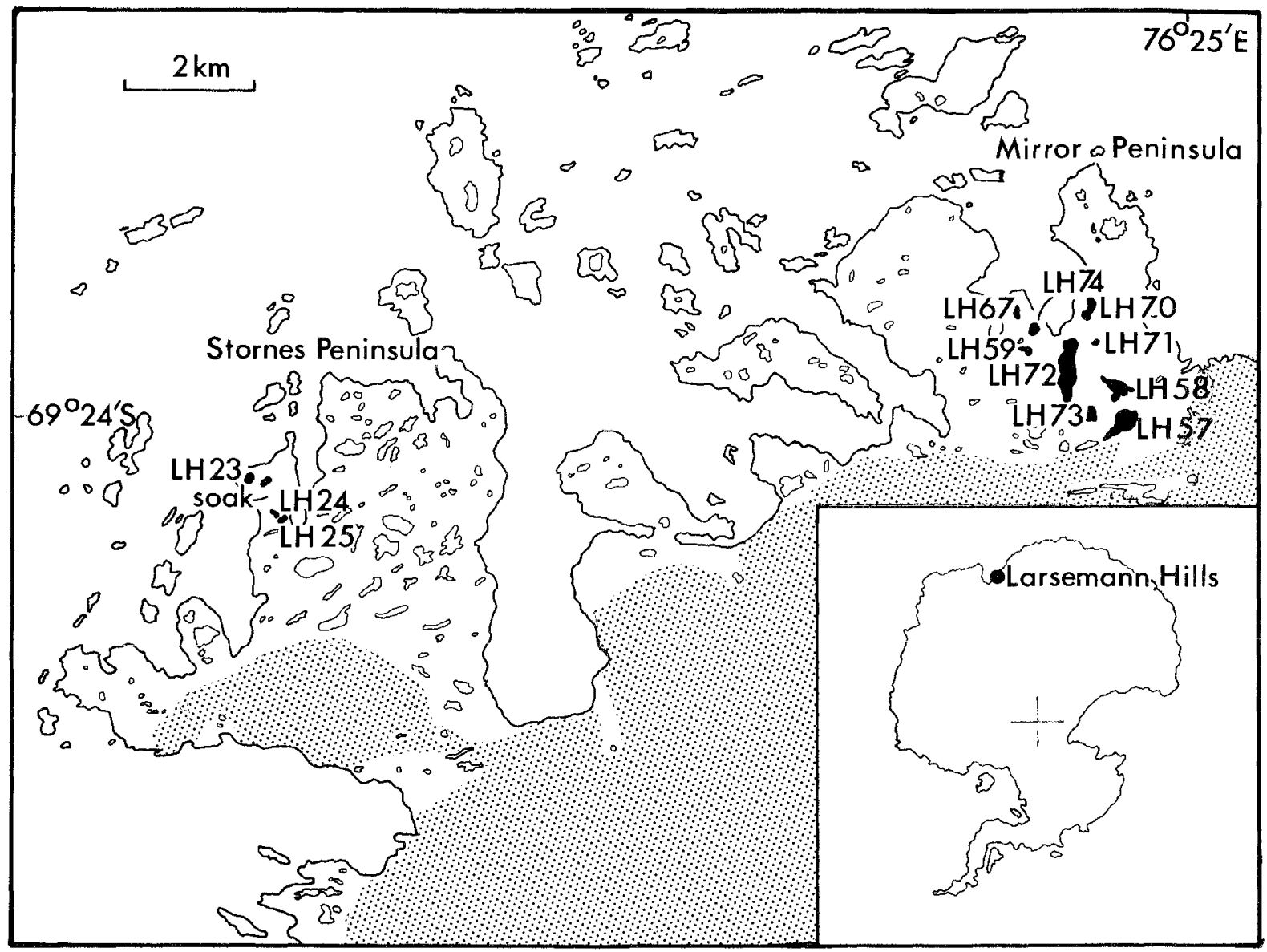

FIG. I - Map of the Larsemann Hills showing the location of the lakes (irregular outlines) and the thirteen sampled lakes (filled outlines). The LH numbers refer to the scheme originated by Gillieson et al. (1990). The area of permanent snow and ice is shaded. The inset map shows the location of the Larsemann Hills in relation to the continent.

\section{RESULTS}

\section{Identification}

The Larsemann Hills were visited on five occasions (including visits made for me) during the 1990/91 and 1991/92 summers, and the results of these surveys are given in tables 1 and 2 . (The Stornes Peninsula was only visited once, in January 1991.) Since the primary objective of this srudy was to survey the rotifers, most of the discussion that follows concentrates on rotifer matters. However, the fauna of this area is poorly known, and brief notes on all the invertebrates found are included.

\section{Protozoa}

Even though the collecting methods employed were not ideal for protozoa, specimens were observed in most samples. Generally, those seen on the bottom of the freshwater lakes were oval/elliptical, transparent or pale brown ciliates, small ciliates with spikey tufts - holotrichia, large solitary paramecium-type ciliates and a few small amoebae.
Plathyhelminthes

Solitary specimens of a small blind acoel were found in the sediments of Lake Scandrett and LH24 (tables 1, 2).

\section{Tardigrada}

At least two species of smooth tardigrade were seen in the freshwater lakes. These would appear to belong to the Isohysibiusgroup. In addition Milnesium tardigradum Doyere was found in terrestrial mosses at the edge of Lake Scandrett

\section{Rotifera}

Many of the species recorded from the Larsemann Hills are common rotifers that are regularly encountered in the Antarctic and elsewhere, and as such require little comment. The section that follows concentrates, therefore, on the more interesting problems of identification and on their distribution.

Monogononta

Eleven species were recognised. 
TABLE 1

Distribution* of the invertebrates found in the nine lakes sampled on the Mirror Peninsula

\begin{tabular}{|c|c|c|c|c|c|c|c|c|c|}
\hline $\begin{array}{l}\text { Lake name/ } \\
\text { ref. no. } \dagger\end{array}$ & $\begin{array}{l}\text { Scandrett } \\
\mathrm{LH} 72\end{array}$ & $\begin{array}{c}\text { Discussion } \\
\text { LH74 }\end{array}$ & $\begin{array}{l}\text { Sibthorpe } \\
\text { LH58 }\end{array}$ & LH73 & $\begin{array}{c}\text { Progress } \\
\text { LH57 }\end{array}$ & LH67 & $\begin{array}{c}\text { Reid } \\
\text { LH70 }\end{array}$ & LH59 & LH7I \\
\hline Length (m) & 945 & 190 & 175 & 225 & 600 & 165 & 300 & 150 & 120 \\
\hline Breadth $(\mathrm{m})$ & 195 & 95 & 165 & 120 & 300 & 75 & 80 & 55 & 60 \\
\hline Max. depth (m) & 10.3 & 4 & 1 & 5.4 & 34 & 5 & 3.8 & 4 & 2.5 \\
\hline Conductivity $\mu \mathrm{S} / \mathrm{cm}$ & 88 & 162 & 162 & 286 & 335 & 620 & $1288-167+$ & 1310 & 1589 \\
\hline $\mathrm{pH}$ & 7.0 & 6.8 & 6.4 & 6.9 & 6.6 & 7.6 & 8.4 & 7.9 & 8.3 \\
\hline Protozoa & + & + & + & + & + & + & + & + & + \\
\hline Plathyhelminthes & + & - & - & - & - & - & - & - & - \\
\hline \multicolumn{10}{|l|}{ Tardigrada } \\
\hline Isohypsibius 2 spp. & + & + & + & - & + & + & + & + & - \\
\hline \multicolumn{10}{|l|}{ Rotifera } \\
\hline Cephalodella sterea & + & - & + & + & $?$ & - & - & - & - \\
\hline C. ventripes & + & - & - & - & $?$ & - & - & - & - \\
\hline \multicolumn{10}{|l|}{ Collotheca ornata } \\
\hline cornuta & +++ & + & - & - & - & - & + & - & - \\
\hline Encentrum mustela & + & - & - & - & - & - & + & - & - \\
\hline E. spatitium & + & - & - & - & - & - & + & + & + \\
\hline Epiphanes senta & - & - & - & - & - & - & +++ & + & ++ \\
\hline Lepadella patella & + & + & - & + & + & + & + & + & + \\
\hline L. acuminata & - & - & - & - & - & - & - & - & - \\
\hline Notholca sp. & + & + & - & + & + & + & +++ & + & ++ \\
\hline Ptygura crystallina & + & - & - & - & - & - & + & - & - \\
\hline Resticula gelida & - & - & - & - & - & - & + & - & - \\
\hline Adineta grandis & - & + & - & - & - & - & ++ & - & + \\
\hline Adineta sp. & - & - & - & - & - & - & - & - & - \\
\hline Habrotrocha constricta & + & - & + & - & - & - & + & - & - \\
\hline Philodina gregaria & - & - & - & - & - & - & +++ & + & - \\
\hline Philodina sp. 1 & ++ & - & $?$ & - & $?$ & - & + & - & - \\
\hline Philodina sp. 2 & + & + & + & + & + & - & - & - & - \\
\hline Nematoda & - & + & + & - & - & - & + & - & - \\
\hline \multicolumn{10}{|l|}{ Arthropoda } \\
\hline Daphniopsis studeri & +++ & + & - & - & + & - & +++ & - & - \\
\hline Acanthocylops mirnyi & + & - & - & - & + & - & - & - & - \\
\hline
\end{tabular}

$*$ Key: $-=$ not found $+=$ present $++=$ common $+++=$ abundant $?=$ not positively identified

$\uparrow$ The LH (Larsemann Hills) numbers (Gillieson et al. 1990).

+ Higher conductivity recorded in the spring when this lake was ice-covered. Lower value in the summer open-water period.

\section{Epiphanes senta (O.F. Müller)}

This species was found in those lakes of higher conductivity and close to the shore (tables 1,2). Males were found in Lake Reid (LH70) and LH71, which had the largest E. senta populations.

Epiphanes senta is cosmopolitan and is usually found in small pools enriched with excreta of domestic animals. In the Antarctic, it is found in pools enriched by penguins and seals. It has been reported from the McMurdo Sound area (Murray 1910, Armitage \& House 1962, Dougherty \& Harris 1963); from fresh and brackish pools in eastern Antarctica, in the Bunger Hills (Korotkevich 1958), at Haswell Island (Kutikova 1958b, Donner 1972), from the South Shetland Islands (de Paggi 1982) and the South
Orkney Islands (Dartnall \& Hollowday 1985); from the sub-Antarctic at Macquarie Island (Dartnall 1993); and from Heard Island (Dartnall 1995).

Notholca sp. (fig. 2A, B)

Notholca's were found in every lake except the soak, LH25 and LH58. The specimens from the larger freshwater lakes - Scandrett, Discussion, Sibthorpe and Progress - had a circular/oval lorica $200 \mu \mathrm{m}$ long, only lightly striated and decorated with six short, anterior spines. Those from the brackish lakes had a "U-shaped" lorica but otherwise were identical (fig. 2A, B). The mastax has malleate trophi. No males were seen. 
TABLE 2

Distribution* of the invertebrates found in the four lakes sampled on the Stornes Peninsula

\begin{tabular}{|c|c|c|c|c|}
\hline $\begin{array}{l}\text { Lake name/ } \\
\text { ref. no. } \dagger\end{array}$ & Soak & LH23 & LH25 & LH24 \\
\hline Length $(\mathrm{m})$ & & 105 & 90 & 150 \\
\hline Breadth (m) & & 90 & 45 & 60 \\
\hline Depth (m) & 0.2 & 4.6 & 7.2 & 4.8 \\
\hline Cond uctivity $\mu S / \mathrm{cm}$ & $146-273$ & 280 & 822 & 961 \\
\hline $\mathrm{pH}$ & $7.6-9.6$ & 7.8 & 8.6 & 8.0 \\
\hline Protozoa & + & + & + & + \\
\hline Plathyhelminthes & - & - & - & + \\
\hline Tardigrada & & & & \\
\hline $\begin{array}{l}\text { Isobypsibius } 2 \text { spp. } \\
\text { Rotifera }\end{array}$ & + & + & + & + \\
\hline Cephalodella sterea & - & - & - & - \\
\hline $\begin{array}{l}\text { C. ventripes } \\
\text { Collotheca ornata }\end{array}$ & - & - & - & - \\
\hline cornuta & + & + & - & + \\
\hline Encentrum mustela & - & - & + & - \\
\hline E. spatitium & + & + & + & - \\
\hline Epiphanes senta & - & + & - & + \\
\hline Lepadella patella & + & + & + & + \\
\hline L. acuminata & - & + & - & - \\
\hline Notbolca sp. & - & ++ & - & + \\
\hline Ptygura crystallina & - & - & - & - \\
\hline Resticula gelida & - & - & - & - \\
\hline Adineta grandis & - & - & - & +++ \\
\hline Adinetasp. & - & - & - & - \\
\hline Habrotrocha constricta & + & - & - & - \\
\hline Philodina gregaria & - & + & - & - \\
\hline P. sp. 1 & + & - & - & - \\
\hline P. sp. 2 & + & - & - & - \\
\hline Nematoda & + & + & + & + \\
\hline Arthropoda & - & +++ & - & - \\
\hline $\begin{array}{l}\text { Daphniopsis studeri } \\
\text { Acanthocylops mirnyi }\end{array}$ & - & - & - & - \\
\hline
\end{tabular}

* Key: $-=$ not found $+=$ present $++=$ common $+++=$ abundant.

+ LH (Larsemann Hills) numbers (Gillieson et al. 1990).

The Larsemann Hills specimens appear to belong to the squamulalsalina group. Notholca verae Kutikova has been reported from the nearby Vestfold Hills (Everitt 1981) and from the Bunger Hills (Kutikova 1958a), and might have been expected to be the species present in the Larsemann Hills. Different species of Notholca have been found right round the Antarctic (Dartnall \& Hollowday 1985, Dartnall 1993, 1995). Currently the identification of the group is based on morphometric comparisons. Details of the trophi and chemical fingerprinting are obvious areas for furure studies.

\section{Lepadella patella (Müller)}

One of the commonest rotifers encountered, this was found in all lakes sampled except Lake Sibthorpe.
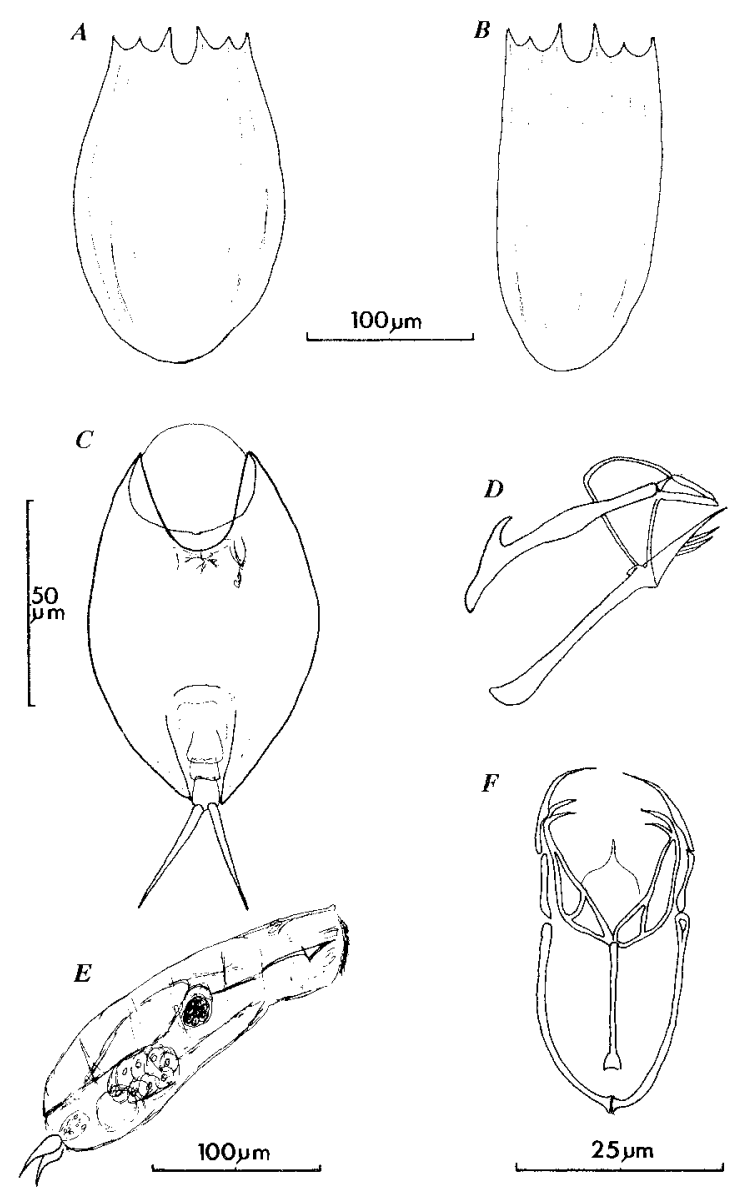

FIG, 2 - (A, B) Notholca sp., dorsal view of lorica: (A) "freshwater" specimen; (B) "brackish" specimen. (C) Lepadella acuminata, ventral view. (D) Cephalodella sterea: lateral view of trophi. $(E, F)$ Encentrum spatitium: (E) Lateral view; (F) trophus of specimen from Lake Scandrett.

Lepadella patella is cosmopolitan and has been reported from both Macquarie Island and Iles Kerguelen by Russell in 1959. Other antarctic locations include the Obruchev and Bunger Hills (Korotkevich 1958, Kutikova 1958b), the Thalla Hills (Opalinski 1972b), Langhovde (Sudzuki 1964) and at Heard Island (Dartnall 1995).

Lepadella acuminata (Ehrenberg) (fig. 2C)

Just one specimen was found in LH23. This specimen, which was found in the material collected as L. patella, was only recognised when examined under medium power.

Lepadella acuminata is cosmopolitan; in the Antarctic it has been reported from Iles Kerguelen (Russell 1959) and Macquarie Island (Dartnall 1993).

Cephalodella sterea (Gosse) (fig. 2D)

Just a few specimens of this small rotifer were found in four of the freshwater lakes (table 1). 
Cephalodella sterea has been reported from the Antarctic before - in the Obruchev Hills (Korotkevich 1958) and at Heard Island (Dartnall 1995).

\section{Cephalodella ventripes (Dixon-Nuttall)}

Just one specimen of this species was found in Lake Scandrett. It was amongst the material collected as C. sterea.

Cephalodella ventripes has been reported from the Antarctic only once before at Heard Island (Dartnall 1995).

\section{Resticula gelida (Harring \& Myers)}

Solitary individuals were found Lakes Scandrett and Reid. Resticula gelida is cosmopolitan and has been reported from Adelaide Island (Dartnall 1980), from brackish pools at Signy Island (Dartnall \& Hollowday 1985) and from Heard Island (Dartnall 1995). The closely related $R$. nyassa has been reported from Macquarie Island (Dartnall 1993).

\section{Encentrum spatitium Wulfert (fig. 2E, F)}

This species, which is an active predatory rotifer with protrusible forcipate trophi and a soft, elastic body, was found in seven of the lakes sampled (tables 1, 2). The trophi of those specimens from the brackish lakes have a distinctive, chunky appearance, when compared with those from Lake Scandrett, the manubria and intrameallei being particularly broader, but they were identical in all other respects. The small, paired toes have swollen bases.

Encentrum spatitium is a European species of inland saline waters. Its presence in the Larsemann Hills lakes was therefore surprising, being the first report in the Southern Hemisphere. However, it was also found in some of the saline lakes in the Vestfold Hills and, as will be described in a future paper, in coastal pools on South Georgia.

\section{Encentrum mustela (Milne)}

This species was found in just two of the lakes on the Mirror Peninsula (table 1). Like E. spatitium, it is a solitary, predatory species. In Europe it is regarded as a cold stenotherm.

Encentrum mustela probably has a circumpolar antarctic distribution. It has been reported from Signy Island (Dartnall \& Hollowday 1985), from Macquarie Island (Dartnall 1993) and from Heard Island (Dartnall 1995).

\section{Ptygura crystallina (Ehrenberg)}

This species was found in in just two of the lakes on the Mirror Peninsula (table 1).

Ptygura crystallina is a cosmopolitan species, which has been reported from the Antarctic and Subantarctic four times before; from Signy Island (Dartnall \& Hollowday 1985), from the Vestfold Hills (identified as Ptygura sp. by Everitt [1981] but now confirmed as P. crystallina) and from Macquarie Island (Dartnall 1993).

\section{Collotheca ornata cornuta (Dobie)}

Collotheca ornata cornuta has a worldwide distribution. It has been reported from the antarctic region several times and undoubtedly has a circumpolar distribution. It was first recorded in 1910 (reported as Floscularia cornuta) by Murray, who found it at Cape Barne and Cape Royds (Murray 1910), and has subsequently been reported from these locations and nearby by Armitage \& House (1962), though their record is for C. omata, and by Dougherty \& Harris (1963). It has been reported from eastern Antarctica from pools in the Obruchev Hills (Korotkevich 1958, Kutikova 1958b), from Signy Island (Dartnall \& Hollowday 1985), from Macquarie Island (Dartnall 1993) and from Heard Island (Dartnall 1995).

\section{Bdelloidea}

Six species of bdelloid rotifer were recognised.

\section{Adineta grandis Murray}

This large (to $700 \mu \mathrm{m}$ ) brown rotifer was only found in those lakes with the highest conductivities. It is a viviparous species and some specimens were observed to have five developing young in their bodies. As with all members of the genus, the normal bdelloid wheel organ is absent and consequently all Adinetids creep or glide over the bottom and do not swim. Adineta grandis is only found in the Antarctic and probably has a circumpolar distribution. So far it has been reported from the McMurdo Sound area (Murray 1910, Dougherty \& Harris 1963, Spurr 1975), from Haswell Island (Donner 1972, Opalinski 1972a) and from Signy Island (Dartnall \& Hollowday 1985)

\section{Adinetasp.}

Only a few specimens of this species were found, in Lakes Scandrett and Discussion. It is a relatively small $(250 \mu \mathrm{m})$, transparent species with no distinguishing marks and may therefore be a juvenile.

\section{Habrotrocha constricta Dujardin}

This pellet-forming bdelloid was seen creeping on the bottom of a number of lakes (tables 1,2). Of medium size (up to $400 \mu \mathrm{m}$ ) the body was smooth and a pale yellow-brown. The ramate trophi are covered with fine striae and have a characteristic dental formula of $8 / 8$ unci teeth. Several oval eggs $(80 \times 50 \mu \mathrm{m})$ were seen.

According to Bartos (1951), Habrotrocha constricta is cosmopolitan and it has been reported from the Antarctic several times. It was first reported by Murray (1910) from the McMurdo Sound area and has subsequently been reported at Signy Island (Jennings 1976, Donner 1980, Dartnall \& Hollowday 1985) and the Vestfold Hills (Everitt 1981). 


\section{Philodina gregaria Murray}

This very large rotifer, which is in excess of $600 \mu \mathrm{m}$ long and is bright red with a pair of conspicuous, orange eye-spots, was found in lakes with the higher conductivities on the Mirror Peninsula (table 1) and in LH23 on the Stornes Peninsula (table 2).

Like Adineta grandis, Philodina gregaria is only found in the Antarctic. Descibed by Murray in 1910 from the lakes and pools at Cape Royds and Cape Barne, it has been reported from Haswell Island (Donner 1972, Opalinski 1972a); from the Vestfold Hills (Everitt 1981); on the Antarctic Peninsula, at Red Rock Ridge, Stonington (Schmitt 1945) and at Ablation Point, Alexander Island (Heywood 1977); and at Signy Island (Dartnall \& Hollowday 1985).

\section{Philodina sp. 1}

This large ( $>400 \mu \mathrm{m}$ ), brown bdelloid was most common in Lake Scandreti. It was most numerous on the bottom, bur a number of specimens were distributed throughout the water column (first visit when the lake was covered with ice $0.9 \mathrm{~m}$ thick). It is a very chunky species with a large pair of cilary discs and orange eye-spots; the trophi had a dental formula of $3 / 3$ or $3+1 / 3+1$. The dorsal antennae appear to be twosegmented. An oviparous species, it lays pale-brown, oval eggs with a single polar knob $(100 \times 75 \mu \mathrm{m})$.

\section{Philodina sp. 2}

This species is much smaller ( $300 \mu \mathrm{m}$ long) and slimmer than Philodina sp. 1, pale red, and with a $2 / 2$ dental formula. It was found in relatively small numbers in the larger freshwater lakes (table 1) and the soak (table 2).

\section{Nematoda}

Nematodes were found in the benthic sediments of a number of lakes. Two species, unidentified, were recognised in the field.

\section{Arthropoda}

Just two species were present in the freshwater lakes; the cladoceran Daphniopsis studeri Rühe and the copepod Acanthocyclops mirnyiBorutzky and Vinogradov. Daphniopsis studeri was the largest and most abundant species found. Large numbers of males were found in Lake Scandrett during the February visit. This species is commonly recorded from the subantarctic islands of the Southern Indian Ocean. Acanthocyclops mirnyi was also found in the larger freshwater lakes. It was first found in the Bunger Hills (Korotkevich 1958).

\section{DISCUSSION}

Overall, the range of lake types is not particularly great and the fauna is essentially similar throughout. Nevertheless, it is possible to discern certain correlations between habitat and fauna. Thus, both species of Cephalodella, Philodinasp. 1 and the copepod Acanthocyclops mirnyi are found in the freshest lakes while Epiphanes senta, Adineta grandis and Philodina gregaria predominate in those with a higher conductivity (brackish)

Although protozoans, turbellarians, gastrotrichs, nematodes, rotifers, tardigrades, annelids and arthropods have all been reported from lakes and pools on the subantarctic islands and from the Antarctic Continent (Heywood 1967, 1972), they are not distributed throughout the antarctic region, and Dartnall \& Heywood (1980) have noted a decline in their variety with increasing latitude. Indeed, gastrotrichs, annelids and, amongst the arthropods, anostracans, ostracods, collembolans and mites are entirely absent from the Larsemann Hills lakes.

Even those ubiquitous groups that are present show a marked decline in the number of species, when compared with more northerly locations. Thus, there is only one species of cladoceran and one copepod in the Larsemann Hills, compared with the five cladocerans and three copepods at South Georgia (Darmall \& Heywood 1980); three cladocerans and two copepods at both Signy (Heywood, Dartnall \& Priddle 1979) and Macquarie Island (Evans 1970 and the late D.G. Frey, pers. comm.); and four cladocerans and two copepods at Heard Island (Dartnall 1995). This difference is even more marked for the rotifers with 55 species at South Georgia (from a recent unpublished survey), 39 at Macquarie Island (Dartnall 1993) and 38 at Signy Island (Dartnall \& Hollowday 1985), compared with the 17 recorded in the present survey.

On the Antarctic Continent only the McMurdo Sound area with 20 rotifer species (Murtay 1910, Dougherty \& Harris 1963, Donner 1972, Cathey et al. 1981) has a comparable list. Rotifers have been reported from several other continental antarctic locations, but these are incomplete surveys and list less than eight species (for a complete review, see Dartnall \& Hollowday 1985). These incomplete surveys invariably record Epiphanes senta, Adineta grandis, Habrotrocha constricta and Philodina gregaria. All of the rotifers found in the Larsemann Hills have been reported from or, in the case of Encentrum spatitium, have subsequently been found in the Antarctic/sub-Antarctic,

The finding of more species of Monogononta (11) than Bdelloidea (6), though a lower ratio than the $28: 9$ recorded for Signy Island (Dartnall \& Hollowday 1985), does confirm their observation that Monogononta are the dominant rotifer group in antarctic aquatic habitats, and finally lays to rest Murray's 1910 observation (where the ratio was 6:14), and the subsequent prevalent view that bdelloids are the principal rotifer group in the Antarctic. Even so the bdelloid Philodina gregaria remains easily the most abundant species.

The lakes and pools of the Larsemann Hills provide a series of fresh to slightly brackish habitats that are readily accessible and contain a rich and varied fauna very typical of the Antarctic region. As one might expect, the fauna includes the endemic rotifers Philodina gregaria and Adineta grandis plus a number of cosmopolitan ones. Of special interest, however; is the presence of the rotifers Cephalodella sterea and C. ventripes, also reported from Heard Island 
(Dartnall 1995), and of the copepod Daphniopsis studeri, which is found on the subantarctic islands of the southern Indian Ocean, because of the links these distributions indicate.

\section{ACKNOWLEDGEMENTS}

My thanks to the Australian Antarctic Division: to Dr Jim Burgess, Dr Christian Bronge, Dr Andrew McMinn and Dominic Hodgson for their help in the field; to Dr Nic Roberts for collecting additional samples and to the pilots of Helicopter Resources, especially Steve Jones, for the flights to and around the Larsemann Hills.

\section{REFERENCES}

Armitage, K.B. \& Housh, H.B., 1962: A limnological reconnaissance in the area of McMurdo Sound, Antarctica. Limnol. Oceanogr. 7: 36-41.

Bartos, E., 1951: The Czechoslovak Rotatoria of the Order Bdelloidea. Vest. Cesk. Spol. Zool. 15: 251-500.

Cathey, D.D., Parker, B.C., Slmmons, G.M. Jnr, Yongue, W. H. JNR \& VAN BRUNI, M.R., 1981: The microfauna of algal mats and artificial substances in southern Victoria Land lakes of Antarctica. Hydrobiologia 85: 3-15.

DartNat., H.J.G., 1980: Freshwater biology at Rothera Point, Adelaide Island: 1. General description of the pools and the fauna. Br. Antarct. Surv. Bull. 50: 51-54.

Dartnall, H.J.G., 1993: The Rotifers of Macquarie Island. ANARE Res. Notes 89: 41pp

DarTnail, H.J.G., 1995a: The Rotifers of Heard 1sland: preliminary survey, with notes on other freshwater groups. Pap. Proc. R. Soc. Tasm. 129: 7-15.

Darinali, H.J.G. \& HeYwood, R.B., 1980: The freshwater fauna of South Georgia. Br. Antarct. Surv. Bull. 50:115118 .

Dartnali, H.J.G. \& Hollowday, E.D., 1985: Antarctic Rorifers. Br. Antarct. Surv. Sci. Rep. 100: 46pp.

De Paggi, S.B.J., 1982: Notholca walterkostei sp. nov. y osrros Rotiferos dulceacuicolas de la Peninsula Potter. Isla 25 de Mayo (Shetland del Sur, Antartida). Rev. Asoc. Cienc Nat. Litoral. 13: 81-95.

DONNER, J., 1972: Bericht über funde von Radertieren (Rotatoria) aus der Antarktis. Pol. Arch. Hydrobiol. 19: 251-252.

Donner, J., 1980: Einige neuc Forschungen über bdelloide Rotatorien Besonders in Boden. Rev. Ecol. Biol. Sol. 17: $125-143$

Dougherty, E.C. \& Harris, L.G., 1963: Antarctic Micrometazoa: Fresh-water species of the McMurdo Sound area. Science 140: 497-498.

Evans, A.J., 1970: Some aspects of the ecology of a calanoid copepod, Pseudoboeckella brevicaudata Brady 1875 , on a subantarctic island. ANARE Sci. Rep. 110: 100 pp.

EvfritT, D.A., 1981: An ecological study of an Antarctic freshwater pool with particular reference to tardigrada and rotifera. Hydrobiologia 83: 225-237.
Gildeson, D. , Burgess, J., Spate, A. \& Cochrane, A., 1990: An atlas of the lakes of the Larsemann Hills, Princess Elizabeth Land, Antarctica. ANARE Res. Notes 74: $173 \mathrm{pp}$.

Hrywood, R.B., 1967: The freshwater lakes of Signy Island and their fauna. In Smith, J.E. (Organizer): A discussion on the terrestrial Antarctic ecosystem. Phil. Trans. R. Soc. Ser: B 252, No, 777: 347-362

Htywoon, R. B., 1972: Antarctic Limnology; a review. Br. Antarct. Surv. Bull. 29: 34-65.

Hrywoon, R.B., 1977: A limnological survey of the Ablation Point area, Alexander Island, Antarctica. Phil. Trans. $R$ Soc. Ser. B 279: 39-54

HeYwoOn, R.B., Dartyali, H.J.G. \& Pridole, J., 1979: The freshwater lakes of Signy Island, South Orkncy Islands, Antarcrica. Br. Antarct. Surv. Data 3: $46 \mathrm{pp}$.

Jannives, P.O., 1976: Ecological studies on Antarctic tardigrades and rotifers. Unpubl. PhD thesis, University of Leicester: $100 \mathrm{pp}$.

KOROTKLVICH, V.S., 1958: Nasalinie vodocmov oazisov v Vostochnoy Antarktide. Inf. Byull. sov. antarkt. Eksped. 3: 91-98. (Translated into English, 1964: Concerning the population of water bodies in the oases of East Antarctica. Sov. Antarct. Exped. Inf. Bull. 1: 154-161.)

Kutrkova, L.A., 1958a: 0 novoy kolovratke v Antarkcide. Inf. Byull. sov. antark. Eksped. 2: 45-46. (Translated into English, 1964: A new rotifer from the antarctic. Sov. Antarct. Exped. Inf. Bull. 1: 88-89.)

KUTIKova, L.A., 1958b: K fauna kolovratok s poberezh'ya Vostochnoy Antarktide. Inf. Byull. sov. antarkt. Eksped. 3: 99. (Translated into English, 1964: Rotifers from the coast of East Antarctica. Sov. Antarct. Exped. Inf. Bull. 1: 162.

Murray, J., 1910: Antarctic Rotifera. In Murray, J. (Ed.): BRITISH ANTARCTIC EXPEDITION. 1907-09. REPORTS ON THE SCIENTIFIC INVESTIGATIONS, BIOLOGY. VOL. 1. William Heineman: 41-65, pls 9 13.

OPA.INSKI, K.W., 1972a: Freshwater fauna and flora in Haswell Island (Queen Mary Land, eastern Antarctica). Pol. Arch. Hydrobiol. 19: 377-381.

OpALINSKI, K.W., 1972b: Flora and fauna in freshwater bodies of the Thalla Hills oasis (Enderby Land, eastern Anrarctica). Pol. Arch. Hydrobiol. 19: 383-398.

Roboril, C. \& Lovisoio, D., 1972: Pyrophosphate and ethylenediaminetetra-acetate as relaxants for lower invertebrates prior to fixation. Stain Technol. 47(1): $37-$ 38.

Russiel, C.R., 1959: Rocifera. Rep. BANZ Antarct. Res. Exped. 1929-1931. Ser. B 8: 81-88.

Russel., C.R., 1961: A simple method of permanently mounting Rotifera trophi. J. Quekett microsc. Club 5: 384-386

Schmirt, W.L., 1945: Miscellaneous zoological material collected by the United States Antarctic Service Expedition, 1939 1941. Proc. Am. philos. Soc. 89: 297.

Spurr, B. , 1975: Limnology of Bird Pond, Ross Island, Antarctica. N. Z. J. Mar. Freshw. Res. 9: 547-562.

SUDzcik, M., 1964: On the microfauna of the Antarctic region, 1. Moss-water community at Landhovde. JPN Antarct. Res. Exped. Sci. Rep., Ser. E Biol. 19: 1-41.

(accepted 15 June 1994) 